Participatory Educational Research (PER)

Special Issue 2015-I, pp. 101-131, June, 2015

Available online at http://www.partedres.com

ISSN: 2148-6123

http://dx.doi.org/10.17275/per.15.spi.1.8

\title{
Multicultural Education: Challenges and Opportunities for Participatory Education Research: From Clash of civilisations to Co-creation and Co- determination
}

\begin{tabular}{|c|c|}
\hline \multicolumn{2}{|c|}{$\begin{array}{c}\text { Flinders University, University of Indonesia, University of Islamic Studies, } \\
\text { University of South Africa janet.mcintyre@ flinders.edu.au }\end{array}$} \\
\hline Article history & The paper addresses ways for multicultural education to respond to \\
\hline $\begin{array}{l}\text { Received: } \\
01.03 .2015\end{array}$ & $\begin{array}{l}\text { current social, cultural, political, economic and environmental challenges } \\
\text { in increasingly urbanized areas where the divides between rich and poor }\end{array}$ \\
\hline $\begin{array}{l}\text { Received in revised form: } \\
20.06 .2015\end{array}$ & $\begin{array}{l}\text { are widening. Public education needs to address human capacity and } \\
\text { capabilities to live sustainably, because current and future generations } \\
\text { face the prospect of 'food deserts' and increasingly impoverished }\end{array}$ \\
\hline $\begin{array}{l}\text { Accepted: } \\
23.06 .2015\end{array}$ & $\begin{array}{l}\text { communities in cities without adequate resources to maintain a decent } \\
\text { quality of life. Participatory research needs to facilitate the engagement }\end{array}$ \\
\hline Key words: & \\
\hline $\begin{array}{l}\begin{array}{l}\text { culture, diversity, , clash, co- } \\
\text { creation, co-determination }\end{array} \\
\end{array}$ & $\begin{array}{l}\text { security by balancing individual and collective needs in rural and urban } \\
\text { areas. Educators and policy researchers need to work together with many } \\
\text { stakeholders who can contribute diverse ways of knowing to inform } \\
\text { discipline based knowledge and better policy decisions. It will require } \\
\text { enabling everyone to feel that they are represented, respected and heard } \\
\text { within accountable learning communities, supported by a community of } \\
\text { practice. Public Participatory Education in a globalised world needs to } \\
\text { build the capacity of people to become leaders in their own right who } \\
\text { strive not merely for basic needs but also for social and environmental } \\
\text { justice by voicing their concerns strategically at the local and regional } \\
\text { level. }\end{array}$ \\
\hline
\end{tabular}

\section{Introduction}

How should we live should we live and work, in order to respond to the growing challenge of meeting the needs of people living in cities? What do we value and why? What are the implications for human capacity and human capabilities? These questions are inspired in part by Stuart Hall a critical sociologist who asked: What is the social, cultural, economic and environmental context that shapes who gets what, when, why and to what effect?

During my sabbatical in 2014, I explored the issue of sustainability, food, energy and water security as it relates to these ethical questions. This paper is drawn from a forthcoming book, entitled: 'Knowing our place and recognising our hybridity'. Internationally the gap between rich and poor has widened. The price of inequality is born by people and the environment. Most importantly the current social contract does not go far enough to protect the needs of non-citizens, namely young people, asylum seekers as well as the voiceless who are unable to

\footnotetext{
* Correspondence: janet.mcintyre@flinders.edu.au
} 
express their needs. PER needs to focus on the inadequacies of the social contract, in order to uphold social and environmental justice for living systems. This paper:

- Discusses some of my own research and stresses the need for Participatory Education Research to introduce a way to think about what we value and why as a first step for co-creating and co-determining sustainable living.

- Discusses economics and accounting in response to the plea made by Joseph Stiglitz et al (2010) in 'Mis-measuring our lives'. Stiglitz et al (2010: 15) use a multidimensional measure of wellbeing. These are as follows: (1) material living standards (income, consumption and wealth), (2) health, (3) education, (4)personal activities including work, (5) political voice and governance, (6) social connections and relationships,(7) environment (present and future conditions)and (8) insecurity, of an economy as well as a physical nature. Leisure should also be valued. According to Stiglitz et al., the essence of the commissioned work's findings is that wealth needs to include stocks for the future -social, economic and environmental. The way to achieve this is in part through public education. But paradoxically, the valuing of nature holds within it the commodification thesis - if used cynically by the market that it aims to tame. The problem is not only one of externalities that are not factored into calculations of the degradation to the environment, it is a way of thinking and 'being in the world'. The declining conditions of work are based on shifting the extraction of profit to where labour is cheaper and where governments and citizens are less likely to complain about the degradation of the environment. Thus short-term profits are made at the expense of current and future generations.

- Develops an argument based on the notion that -the greater the rate of urbanisation and the growth in the size of cities - the more vulnerable the population becomes in terms of food, energy and water security.

As public educators and policy researchers we need to engage participants to consider the empirical consequences of social, economic and environmental development decisions on the quality of life of current and future generations. Participatory Education Research (PER) needs to draw on diverse ways of knowing (Cruz et al., 2009) that could support effective environmental management. As stressed previously (McIntyre-Mills et al, 2014:111), Churchman's five domains span: logic, empiricism, dialectic, idealism and pragmatism and needs to be extended. We need to take into consideration:

- Non-anthropocentric knowing drawing on the environment as well as knowing through all our senses - including empathy and intuition

- Respect for 'know how' developed through empirical trial and error

- Creativity in maintaining sustainable relationships with the land

- Respect for spiritual awareness, the wisdom of experience as well as the social and natural sciences

- Artistic expression of feelings, perceptions and emotions

- Caring for future generations of life

- 'Phronesis' or Aristotelian wisdom to match the right knowledge in context so as to empower learners through providing them with appropriate pathways to learning.

We know that environmental sustainability and human wellbeing are intimately linked, but there is little knowledge about how this linkage can be built upon to improve both areas. Attempts to address food, energy and water are often based on policy information that is not grounded in citizen experiences and fails to address what we do know about human behaviour 
or choices. The inherent link between engagement in civil society and community wellbeing (rather than the economic bottom line) needs to be the focus of PER through which to explore the nexus across wellbeing, consumption choices and the environment. We need to develop a deeper understanding of how the intangible aspects of perceived wellbeing can be measured. But we also need to measure them in relation to the links across wellbeing and sustainability (Ingold, 1993, Stiglitz et al., 2010).

\section{Multicultural public education needs to focus on human security: food, energy and water}

During my sabbatical I visited the Schumacher Institute in Bristol, a sea port linked with slavery trade through the Royal African Company. I also spent time in South Africa, Japan and Indonesia where the widening gap between rich and poor is evident in Cape Town, Gauteng, Yokohama and Jakarta. In South Africa I visited a range of University departments, research institutes and NGOs including the University of South Africa, the University of Cape Town, and the University of Stellenbosch where the Mindfulness Institute is based. I attended the Mindfulness Matters Conference and listened with interest to the plenary: 'From the ground beneath my feet: towards the distant horizon'. Simon Whitesman who organised the conference focused his plenary on the need to 'be the change'. Delegates stressed that the core challenge is to address the vast differences in the standard of living between the rich and the poor. Mindfulness needs to be translated into co-learning and co-determination.

In South Africa and Indonesia, for example at least $65 \%$ and $75 \%$ of the population respectively will be living in urban areas. Urbanization poses a systemic threat to the survival and sustainability of culture as we know it today. What is the point of raising these concerns? The challenges pose opportunities to provide education and leadership. I would like to discuss the implications of increased urbanization on quality of life and the implications for policy. Food deserts are the likely scenario if more emphasis is not placed on balance, greening cities and supporting small farmers. This paper advocates for public education to address sustainable living. I make the case for:

- Co-determination in regions - new architecture for governance democracy and ethics

- Co-learning and Mindfulness that support building communities of practice

- Supporting learning communities that help us to think across disciplines and cultures, in order to support co-determination of our future within the region.

- Developing new curriculum that is supported by architectures for public learning

- Extending solidarity and protection to all forms of life within a region, rather than limiting protection and thus limiting human security which is dependent on biospheres not national boundaries.

It has been wrongly assumed that growth in the economy will sustain a growing population. We need to understand that the current way of life is unsustainable and that we need to rethink many of the dimensions of modern culture. Culture after all is simply a way of life and a response to the challenges that we face as human beings. The way we think shapes who we are and the sense we make of our daily experiences. Neuroscientists such as Cliff Sarron and Al Kasniak presented at the 'Mindfulness Matters' Conference. Kazniak (2014) stressed in his paper stress that mindfulness research has shown how thinking affects the material body that we inhabit and the way we think shapes the body and the environment on which we depend. The environment affects the body and mind. For example the research by Professors Sarron and Kasniak has found that people who exercise in a natural environment have higher levels 
of concentration than people who exercise in a built up environment.

Thus perhaps it is not too farfetched to hypothesise that the more we decimate the environment the worse it will be for our ability to re-create ourselves when we take a break from learning, working and teaching? Another key finding from neuroscience that is relevant for public education is that the telomeres (or parts of the cell that protect us from aging) are protected when we have a sense of purpose, when we use all our capabilities each day in an environment that is rich in nature and not degraded.

I attended workshops or held conversations with colleagues at Living Hope, Embrace Dignity and Africa Tikum in Cape Town. The concerns they raised were for food security and how it relates to educational and employment opportunities for all especially young people.

The cost of living in first world nations such as the UK also poses the challenge of food security. For example the BBC 1 news on the $29^{\text {th }}$ August reported that families are finding it difficult to 'make ends meet'. Middle class families are shopping more carefully whilst those with low incomes are skipping meals so they can afford to pay the rent. The lack of basics such as three meals a day, affordable heating, safe housing and affordable public transport remain issues for people. Social problems become more evident in Britain as the gap between the rich and poor widens. According to Deborah Mattinson, a former pollster to Gordon Brown:

"Young people (cannot vote) until they are 18 years and many do not vote at 18, because they are disillusioned and it has been suggested that the voting age should be lowered to 16 as they need to be able to stand up for their rights. [She] believes politicians have not begun to grasp the scale of the problem. 'Voter disengagement is getting worse and worse'. She stresses: 'Nobody is really taking it seriously enough' (Mason, 2014: 15).

Food security is also being challenged in South Africa as a result of the move to develop biofuels from sugar cane. In an article entitled: 'There is a gold rush to invest in ethanol', Carnie (2014:5) expresses concerns about the way in which arable land will be used for the production of sugar for fuel. He stresses that the Jozini Dam in Pongolo does not have adequate water supplies. Sugar may not be such a loss to the South African diet - but if other arable land and other crops are used for fuel when they could be used for food - it will become problematic. There is an inadequate emphasis on food production for an ever growing population and there needs to be more emphasis on planning renewable sources of energy. The Food Security Network (Crush, and Fayne, 2010, Battersby, and Crush, 2014, Frayne et al, 2014) has concluded that the reliance on growing food in urban areas whilst a step in the right direction is insufficient to address the needs of an increasingly urbanized population in South Africa. Instead the emphasis needs to be on supporting agriculture and arable land.

The anniversary of Marikane of 44 mineworkers on $15^{\text {th }}$ August 2012 was on $15^{\text {th }}$ August, 2014 provides a point at which we need to pause to consider the state of democracy and governance in South Africa. According to Xalabile (2014):

"[D]uring a recent march to the Ntabankulu municipal offices to protest against inadequate service delivery officials told protesters that "marches don't help anyone because when you march another Marikana will happen". His report reflects that on the one hand, "South Africa is the beacon of hope for the world" and that "truth and reconciliation are possible" and that "the spirit of Ubuntu" or being a person through others can "triumph over Apartheid". But 
that on the other hand, the reality is that Marikane marks a point where South Africa needs to "learn from the risks" through openness and transparency.

But systemic problems will continue to lead to social, economic and environmental injustice unless unemployment and poverty are recognized as priorities that need to be addressed through capacity building, pathways to training and employment supported across the public, private and non-government sectors. For democracy to exist there needs to be opposition and civil society groups who believe that people can voice protest in a frank and fearless manner. But these protests should also respect the axiom that we can be free and diverse to the extent that our freedom and diversity does not undermine the rights of others in this generation or the next.

In South Africa I spent a couple of days in July 2014 and February 2015 with staff at the University of South Africa. They stressed that unemployment needs to be addressed through appropriate educational pathways that recognise the skills of people who do not have formal education (but who do have plenty of life skills). New pathways are urgently in need of recognition as a starting point for entry to further education. They stressed that they did not think about environmental issues per se as a primary concern, but were aware that hunger was an issue for many-particularly women, children and young people with few opportunities in both rural and urban areas. The UCT food security network has published papers on the need to address the challenges in cities that could become 'food deserts'. The flipside of this challenge is to address the need for rural agricultural development opportunities.

The challenge of meeting the needs of the hungry are visible on a daily basis as indicated by the so-called 'bin-pickers' who work through suburban recycle and refuse bins. The struggle for survival is also reflected in the levels of crime. Forty two murders a day occur in South Africa according to my informants at an NGO that provides support called: 'Living Hope' for those who live in 7 areas in Cape Town. One of these areas is Ocean View, where the twenty five thousand people living in poverty face a range of challenges that are reflected in the morbidity and mortality rates. TB is endemic and linked with being HIV positive. The vulnerability of children was recognised by this NGO that provides 'a hot meal and sandwich with fruit to over 7500 children'. This service does not go far enough and with rising numbers of people coming to the cities the threat of hunger will become even greater. Remember this is just one part of the Western Cape and the problem is repeated over and over again across South Africa. According to Battersby and Crush (2012):

"The fact that food deserts have not been explicitly identified or discussed in relation to African cities does not, of course, mean that they do not exist. African cities contain many poor neighbourhoods whose residents are far more food insecure and malnourished than their counterparts in the UK or North America. A baseline food security survey in 11 Southern African cities by the African Food Security Urban Network (AFSUN) for example found that $57 \%$ of households in poor neighbourhoods were severely food insecure and only $17 \%$ were completely food secure (Battersby and Crush 2012).... On average food purchases made up to $50 \%$ of household expenditures. Dietary diversity was very low in all cities with heavy reliance on starch staples. ... Supermarkets undermine local business ...Urban populations tend to rely on informal sector and small business ...to survive ... South Africa's young people is worst affected by the country's unemployment problem, leading some to think there will be a call for a revolution... According to the labour federation, Congress of South African Trade Unions (Cosatu), 'there's no other middle income country in the world with such a high rate of unemployment". 
UNICEF's Generation 2030 Africa" report... stresses that out of South Africa's projected population of 53 million people, 18 million of those would be under the age of 18 . This is reported in the article on 24.com/Web/News24/ entitled: "Over one third of South Africa's population is expected to be under the age of 18 in 2015". The report goes on to say that:

"South Africa was also expected to have $65 \%$ of its population living in urban areas next year, the ninth highest level in Africa. According to the report, in 2050 around $41 \%$ of all births world-wide would take place in Africa, while in the same year 25 people out of every 100 would be African. This was against the expected figures in 2015, where Africans would make up 16 people out of every 100 around the world. In 2015, 40\% of Africa's population was expected to be living in cities, versus over $50 \%$ in $2050 . "$

The prospect of $65 \%$ of South African's living in cities has implications for food, energy and water security. This requires addressing sustainability at the local level in municipalities. For this to occur people need to have a voice and feel that they have a right to voice their ideas openly (Young, 2000, McIntyre-Mills, 2000).

Xabile's (2014) reported on families impacted by Marikane and the concern about the extent to which they can protest. In South Africa there is a need to enable monitoring 'from below' by residents to enhance representation, accountability and sustainability at the local level.

'Local government is "the sphere of government closest to the people; they are elected by citizens to represent them and are responsible to ensure that services are delivered to the community..." (Municipal Service, 2014). Unfortunately services are not being met as people move to the cities in ever larger numbers, for example, according to the Cape Times (Sept $9^{\text {th }}$ 2014):

"Action against Ses'khona: hundreds protested outside court...Hundreds of people gathered outside the Western Cape High Court yesterday amid a legal bid by the City of Cape Town to prevent a group of people - including Ses'khona People's Rights Movement leaders from staging illegal protests." The article explains that townships have insufficient services, infrastructure, houses or land and that some of the protesters had been living in shacks since 1997..."

"The government will have to rethink its anti-poverty initiatives after ...a new report showed that more people in South Africa are poor... The reason is that the upper-bound poverty line, which measures the income needed for essential items after meeting their basic food needs, was recalculated from R620 a month to R799 per month [to include]...airtime, transport and energy costs, as well as changes in diet that are a result of increasing urbanization....The rebased poverty line is R26.70 per person a day ... The proportion of South Africans living in extreme poverty rose 1.5 percentage points - from $20.2 \%$ of the population to 21.7 ....'(Musgrave, 2015: 4).

\section{Participatory policy research needs to support curriculum development and co- determination for social and environmental justice}

The rationale for working at the local, national and international level to support mindful critical and systemic thinking is that with growing urbanization there will be a need for actively engaged young people to address democracy, climate change, food security and sustainable living in urban and regional environments. This has implications for the big issues of the day, namely representation, accountability and sustainability. Learning to live 
sustainably and well requires knowledge spanning social, cultural, economic and environmental issues. This requires social engagement and the fostering of the capacity of members of a community to act together and to be able to transform, existing ways of life (Rose, 2005, Hulme 2009). An open approach to education and respecting diverse ways of knowing is a starting point for people's education and community development. The struggle in South Africa for transformation was typified by student protests during Apartheid for the right to a free and equal education system. In South Africa we are reminded of the need to continue to use education as a means of empowerment.

Hannah Arendt $(1963,1972)$ emphasizes both the potential and risks of the 'banality of evil'. She considered the broad context and every day structures that tempt people to make routinely unethical choices. Arendt stressed the implications of being part of an unquestioned monstrous system that becomes an unquestioned culture and a 'taken for- granted' system of bureaucracy. To avoid taking things for granted it is important to develop critical thinking based on the capability to think at a Meta level about the implications of our living choices (Van Gigch,2003), but also to have in place constitutional structures that protect social and environmental justice for this generation and the next (Jessop, 2009).

Professor Pratikno (2014) stressed at the presentation for the inaugural meeting of the Flinders Culture House (Rumah Budaya) initiative that Indonesia and Australia need to foster regional partnerships through building on friendship networks and soft diplomacy to address opportunities for development. In 2014 Professor Victoria Farrar Myer (Fulbright Distinguished Chair) echoed this plea for greater emphasis on building and re-relationships and emphasized the need to foster collective determinism through public engagement processes. McRae (2014) of the Lowy Institute also echoes this concern:

The current policies on border protection and human security measures in response to the involvement of Australia in military engagements place pressures on relationships. This makes the need for friendship networks through creating communities of practice (networks that addressed shared concerns based on reciprocity and collegiality) and the establishment of learning communities all the more important within our region. McRae (2014) of the Lowy Institute also echoes this concern:

"Finally, people-to-people ties remain a persistent challenge. Abbott's announcement of a new Australian Centre for Indonesian Studies is a positive initiative, as is the Coalition's signature New Colombo Plan. Neither though is a replacement to committing the resources required to promote Indonesian literacy in Australia. This requires both maintaining teaching infrastructure for Indonesian language in Australia, as well as promoting career options that would encourage Australians to attain Indonesia literacy" ( McCrae, 2013).

Flinders has created a bridging (Jembatang) project to assist with building regional friendships. Praktino, Rektor of Gadja Madah, Dr. Adib Shomad (2014) and Prof. Dr. Dede Rosyada, Director of Islamic Higher Education, Ministry of Religious Affairs emphasized the need to develop educational opportunities in Indonesia and Australia, respectively in their plenary address, doctoral thesis and submitted paper. The following statistics were presented by Praktino and Akbar Susamto (2014) at a seminar at Flinders University in which he stressed that the size of the Indonesian economy would increase from the $16^{\text {th }}$ largest to the $7^{\text {th }}$ largest economy in the world by 2030. Praktino emphasised that Indonesian consumers would grow from 45 to 145 million and that 55 million skilled workers in the current Indonesian economy would grow to 135 million workers. Whilst currently these workers 
generate 0.5 trillion Australian dollars this will grow to 1.8 trillion in consumer services, agriculture, fisheries and education by 20130 ".

Shaping the policy direction of education becomes a priority to protect food and human security. The Springer Encyclopedia of Food and Agricultural Ethics (McIntyre-Mills, 2013) provides an overview of the landscape of this complex field, defined by intersections spanning social, cultural, political, economic and environmental contributions from the social and natural sciences pertaining to the ethical production and consumption of food. My contribution makes a case is made for those who are not protected by the social contract, including young people, non-citizens, the disabled, sentient beings and the environment on which we all depend. It highlights the empirical contradictions and theoretical tensions that have implications for social and environmental justice.

In terms of public policy, Australia has announced the importance of studying Indonesian and fostering regional ties. But this needs to be supported through more public education supported by a learning community approach to culture and religion as Silverstein and Kaiser (2014) stress that:

"....Islamophobia is so mainstream as to have become part of the norm of our political culture...Multi-ethnic coalitions, built against fear and racism, and rejecting the false homogenising unity of the nation-state, now seem more necessary than ever."

\section{Leadership for transformation to protect human security and a sustainable future requires gender mainstreaming and capacity building}

According to Rosyada (2014) the Ministry of Religious Affairs administers only about $24 \%$, of madrasah - many of which are based in rural areas - while the rest are students of private schools. Thus the role of the government in relation to the provision of non-secular education very low compared with private owned institutions. The Ministry of Religious Affairs (through the Director General of Islamic Education) strives to address the curriculum and to develop the capacity of teachers in all schools as mandated in the constitution.

Designing public education requires enabling participants to address representation, accountability and sustainability. West Churchman's Design of Inquiring Systems Approach (1972) is based on questioning boundaries of inclusion and exclusion when addressing policy issues. West Churchman $(1981,1979)$ also provides a meta approach to examining the socalled 'enemies within' (religion, mortality, politics and aesthetics) when framing how we understand a policy concern. It also helps us to consider the consequences of our choices. It can be usefully applied to address food security as explained below. Developing learning organisations and learning communities could help to create bridges across diversity and strengthen bonds of friendship. Participation in vertical democracy through elections, whilst important needs to be extended to include other forms of participation. In the social context learning to engage in structured dialogues (Christakis and Bausch, 2006, Christakis and Flanagan, 2010) could be helpful as a way to consider where and when to draw the policy line. Testing out ideas requires preserving freedom, space for doubt, diversity and disagreement to the extent that diversity does not undermine the right to freedoms of others. An open approach to design and to research could be extended through acknowledging the praxis knowledge associated with protecting the environment and living systems of which we are part. Research needs to span consciousness, cultural studies and systemic praxis to link the notion of relationships between humans and the land as a source of wellbeing and the broader 
societal need for environmental protection and effective ecosystem management. The challenges are to address planetary issues. Thus when framing research it is important to realize that the wellbeing of individual citizens cannot be protected unless the global commons is protected. An axiom to guide secular and faith based education that fosters social and environmental justice for all is based on considering the consequences of our choices in the short, medium and long term and that we can be free and diverse in our praxis (thinking and practice) to the extent that it does not undermine the rights of others.

New local forms of engagement and governance (Held, 2004) are needed to protect residents against environmental hazards and the subsequent economic and social consequences. We need a new architecture for governance democracy and ethics as well as mindfulness to support communities of practice within learning communities. Major challenges in local communities include the need to achieve or maintain: (a) access to safe housing (including energy and water), appropriate education and employment; within (b) liveable cities; that are in turn supported by (c) sustainable regions.

Research (McIntyre-Mills et al 2014) tests the principle of subsidiarity, namely that decisions need to be taken at the lowest level possible through the wellbeing and environmental stewardship score card that adapts and extends the Max-Neef Human Development Index. The latter provides the architecture for applying the Aarhus Convention (1998) based on the right to participate and the right to freedom of information on issues pertaining to local environmental wellbeing concerns. The engagement architecture that we develop and test enables diverse opinions to be mapped and scored in terms of social, economic and environmental indicators of what works why and how to support personal and environmental wellbeing through exploring perceptions. Participation through awareness and consciousnessraising (McIntyre-Mills, 2010) influences the way in which people think about boundaries. PER could help particpants in formal and informal places of learning at the local government level to remake connections with others and the environment through valuing the environment and engaging in healthy relationships. This hypothesis is based on the notion of neural plasticity in that the brain shapes the environment and, in turn, is shaped by the environment (Bateson, 1972, Capra, 1996; Greenfield, 2000).

Research needs to build on comparative case studies at secular and non-secular secondary and tertiary institutions in Jakarta and in the surrounding agricultural region to explore policy implications for sustainable development opportunities. PER has implications for the big issues of the day, namely representation, accountability and sustainability. It needs to address a different approach to the way in which we live our lives in terms of our consumption of energy resources, fresh water, transport and meat consumption and the implications for wellbeing and sustainable living (Pretty, 2013). Opportunities exist to create a better balance between rural and urban areas, greening cities (Dryzek, 1999, 2000, 2010) through the creation of urban agriculture in open spaces, on top of, attached to and within buildings.

In South Australia and Australia education and development also needs to support language skills and an understanding of the challenges of living in one of the driest continents. The recent IPCC reports stressed that South Australia will be affected by climate change and that rainfall levels will decrease. The opportunity exists to do the following:

- Teach learners to think systemically and to join up the dots so that they understand the policy implications of their choices. 
- Help them to realize that decisions have consequences in the short, medium and long term.

- Teach them systemic ethics in both secular and non-secular places of learning

- Help places of learning at all levels to connect with communities at the local government level.

- Create a learning organization and learning community approach that supports sustainable living and that reduces the size of our carbon footprint.

With growing urbanization Indonesia also faces challenges such as ensuring that the future economy responds to the need for highly skilled and democratically engaged citizens with a focus on living well and sustainably in city environments that will need to be supported by sustainable agricultural regions. The basis for a democratic and sustainable region rests on regional networks to support human security resting on meeting the quality of life concerns of the current and future generations through securing sustainable cities within sustainable agricultural land. This rests on developing appropriate education and participatory democracy and governance. We need to continue to work towards a better future through:

- Mobilising through scaling up participation with the people who are to be affected by the challenges

- Being the change by drawing on Max-Neef Human Sustainability Index(1991) on 'being, doing, having and interacting) applied to valuing, measuring and managing environmental and human assets - engaging in 'cultural flows' and responding to big issues through small interventions that have ripple effects .

- Drawing on Vandana Shiva (2002) on water as a synecdoche for cultural change and as a way to scale up interventions).

The scope of my teaching and research to date is on rethinking boundaries, relationships, and interconnection and flows spanning being and praxis at multiple levels and applying multiple forms of intervention. The focus is on human rights, discrimination and outlining the notion of a planetary passport. Some key concepts are perceptions, the way in which issues are perceived and the way in which they are framed. The environment of the problem is often limited so that terms of reference deny that we are living systems (Wadsworth, 2010).

Policy needs to develop an alternative vision for education and employment. Through striving to reveal 'in the small new ways of seeing the whole' (Adelman, 2013, 9) communities of practice could co-create new ways of engaging adults and young people in learning for a sustainable South Africa. This could provide lessons for cosmopolitan approaches to rediscovering ways to live through recycling and using resources creatively. It could also foster a sense of stewardship rights and responsibilities (Flannery, 2012) that are translated into new approaches to participatory public education. Where success is valued in terms of living sustainably supported by:

- Socially inclusive communities in which people feel safe, appreciated, respected and happy and in which they are accountable for the governance of sustainable resources ( see Florini 2003, Graham, 2011)

- Economically sustainable communities where people work and live in ways that create and re-create an environment that will continue to support the current and future generations through caring for food, energy and water supplies. Resilience is defined as the adaptive capacity of the physical environment, of an individual or of a group. It concerns factors such as the capacity of members of a community to act together and 
to be able to modify or even transform, existing ways of life (Hulme, 2009; Rose, 2005). Democracy and governance are in need of improvement (Hulme, 2009, Giddens, 2009) and public education lessons learned about sustainable living could help people to become mindful about the consequences of their life choices. It seems to me that awareness of diverse ways of knowing hold the key to human and environmental security.

The focus of my plenary presentation at the Annual International Conference of Islamic Studies in Balikapan in December, 2014 was on Multiculturalism as it relates to complex wicked problems such as poverty and climate change. Wicked problems (comprising many diverse and interrelated variables) are perceived differently by different stakeholders with different values. The AICIS conference endorsed traditional culture, ethnicity and diversity under the philosophy of Five Principles or Pancasila (Indonesian Embassy website) which are:

"1. Belief in One Unitary God, 2. A just and civilized humanitarianism, 3. The unity of Indonesia, 4. Democracy led by principled wisdom and consultation/ representation, 5. Social justice for all the people of Indonesia".

Invited speakers discussed the potential of multiculturalism and the conservative turn that is evident as Islam. My presentation was informed by an adapted version West Churchman's critical systemic approach based on a) testing out ideas with others b) guided by the axiom of freedom and diversity (to the extent that freedom and diversity does not undermine the rights of others or current and future generations of life). Following Turok (2012: 247) I contrast a nuanced argument by Hume and his humility with the approach by Dawkins $(1977,2006)$ :

"Hume presents his scepticism through a dialogue which allows opposing views to be forcefully expressed, but which humbly reaches no definitive conclusion. After all that is his main point: we do not know whether God exists...."

But if we accept that a sense of what is sacred and profane (Douglas,1978) or fair and unfair (De Waal, 2009) is the basis for civilization and evolution then we could accept that the right to draw the line based on reasoning is important for ethics, science, democracy, education and governance. Drawing the line requires working with stakeholders to consider who should be included, what should be included, why and how. But testing out ideas in conversation and dialogue with others has a pre-requisite, namely a willingness to engage in sincere dialogue. Power always needs to be considered in this equation - even if it is not not openly acknowledged - as it plays out in many unacknowledged ways that can be surfaced through dialogue and discourse analysis.

Prof Dede Rosyade emphasized the importance of realizing the potential for Indonesian Islam to be a model for world Islam. The ideal would foster the following: openess and tolerance through supporting democratic engagement to test out ideas and to enable ongoing renewal. But the conservative turn was emphasised by key note speaker, van Bruinessen (2014) who stressed the potential either for Indonesian Islam to set an example of openness and respect for diversity or to move in the direction of fundamentalism. According to Van Bruinessen (2011):

"By 2005 it appeared that a conservative turn had taken place in mainstream Islam, and that the modernist and liberal views that had until recently found relatively broad support within 
Muhammadiyah and NU were increasingly rejected. Both organisations held their five yearly congresses in 2004, and on both occasions the boards were purged of leaders considered as 'liberals', including persons who had rendered great service to their organisations. Many ulama and other Muslim leaders appear preoccupied with the struggle against 'deviant' sects and ideas."

Van Bruinessen discussed the fatwas that have been declared against "secularism, pluralism and religious liberalism as well as interfaith prayer meetings for 'wellbeing and peace'. In his paper, delivered at the ACIS conference - attended by liberals who are linked with the philosophy of Gus Dur /Abdurrahman Wahid - he posed the question as to whether the increase in democracy has allowed this rise in fundamentalism, or whether it is the result of increased links with more fundamentalist ideas elsewhere and the return of graduates who have studied elsewhere to Indonesia.

The argument I presented is that Shiva critiques Hardin's 'Tragedy of the Commons' approach. It applied John Locke's defence of property and the enclosure movements of the $17^{\text {th }}$ Century in Britain. Hardin's core argument is that in the absence of private property there would be lawlessness. His argument supports nationalism and private property. I argue that we need to develop the notion of co-creation and co-determination through education and dialogue that creates unity of purpose and respect for diverse contributions of workers in the city and in agriculture as stressed by the new incoming president Jokowi (2014) who clearly expressed the need for nationalism and expansion:

"Unity and mutual assistance is a requirement to be a big nation, we will never be big if we're divided; we will never be truly free without hard work."

...He also called on citizens - from fishermen to farmers to street food vendors - to work together for the better of the nation..." (Widodo, 2014).

At the ACIS conference (2014) I discussed three basic discourses on the notion of truth along a continuum from one truth based on modernist enlightenment to multiple or no truths, based on extreme versions of post-modernist thinking and I explore a middle ground based on cocreating meanings within context. Each discourse needs to be unpacked in terms of policy discourses and the implications for social and environmental justice (McIntyre-Mills, 2000). I made the case for cosmopolitan post regionalism for food security and human security, because the costs of climate change will place a heavy burden not only on the state but on the surrounding regions. Benhabib (2007) and Archibugi (2010) stress that we need a form of federalist republicanism. Public Education Research could play a role in finding out what forms of co-operation could work at the regional and post national level.

The Sydney Peace Prize Winner, Julian Burnside (2014) highlights that 'without justice there will be no peace'. People who arrive in Australia by boat are not necessarily illegal nor are they criminals. 'Turning back boats', has placed increasing pressure on our relationships within the region. The Sydney Peace prize winner Vandana Shiva $(1998,2002,2011)$ sums up the challenge for this century as one of preventing the commodification of life and the importance of thinking about the interconnections across a number of issues. Human rights underpin all relationships within the nation state and within the broader region. The argument I have developed in 'Reconsidering Boundaries (2014) and in Systemic Ethics (2014) is that Shiva critiques Hardin's 'Tragedy of the Commons' approach. It applied John Locke's defence of property and the enclosure movements of the $17^{\text {th }}$ Century in Britain. Hardin's core argument is that in the absence of private property there would be lawlessness. Hardin's 
classic argument supports nationalism and private property.

This has implications for social and environmental justice. Gro Brundtland (1989) and Mary Kaldor (in Held, 2005: 177) have stressed that human security rests on creating a peaceful world, enshrined in rights expressed in the United Nations Charter (Article 55, 56) and in the constitution of the European Union. As stressed below (see McIntyre-Mills, 2011) rising living costs led to food riots and the so-called Arab Spring, culminating in the Occupy Wall Street Movement. The move towards re-membering and re-connecting with the land echoes the voices of Indigenous First national movements and the implications for the way we live, our relationships, our sense of identity and for new forms of governance and democracy.

A sustainable local community is determined by a sustainable region in which food, energy and water supplies are considered as major determinants for wellbeing. No community can be expected to transform from a high carbon lifestyle (or aspiring to this lifestyle) without feeling part of the design process and owning the decisions as to how resources should be used. Young people, the disabled, asylum seekers and sentient beings (Nussbaum, 2006) along with future generations live 'precarious lives' (Butler, 2005). Nussbaum $(2006,2011)$ stresses the need to address human capabilities within and beyond nation states. She stresses the need to extend the social contract to support the capabilities approach. In discussing human capabilities she stresses health, safety, bodily integrity, education, standard of living, quality of social interaction, productive valued activities, environment, play, basic needs (Nussbaum, 2011, 33-34).

Displaced people who are non-citizens are considered to be outside the frame of reference of state protection. People are displaced through poverty, conflict, food insecurity as a result of shrinking agricultural land, water shortages, growing urbanization, energy shortages associated with using non-renewables, nuclear disasters are examples raised at the United Nations by Vandana Shiva and Maude Barlow. This year the numbers of people moving from Africa (Mali, Libya, Tunisia and Nigeria) have passed 50000 (Scammell, 2015) and are described as 'economic refugees'. This is code for not regarding them as legitimate refugees. In Australia the issue of boat arrivals is once again in the news as Prime Minister Abbot has been accused of paying people smuggles to tow back boats to Indonesia (Whyte, 2015). The conservative 'Australian' ran a series of articles on the extent to which immigrants of different cultures can integrate into Australia. It cited a range of research by leading academics. Riaz Hassan argues that the level of unemployment amongst Australian Muslims (many of whom are first and second generation migrants) is at $12 \%$ which is twice the rate of other religious groups. This non-inclusion is a central reason for alienation (Rogers, 2015) as is the sense of grief and loss as a result of war. Another article in this same edition stressed that one of the groups that is most alienated is the group from Lebanon who are from largely rural areas who entered Australia - not by boats - but as a result of a social policy decision made by the conservative Fraser government to forgo the usual assessment criteria in a bid to enable people to leave Lebanon during the war. So the targeting of boat arrivals seems very misplaced for a range of reasons - even the most conservative policy reviewers (Henderson, 2015) who are targeting the Liberal Primer Minister Fraser's compassion cannot deny that this is an in convenient example to cite. What is needed is more emphasis on creating social inclusion in Australia through education and employment opportunities so that people do not feel drawn to the radical messages preached in a range of contexts.

The reality of the dangers of Islamic State cannot be excluded from a discussion of multiculturalism and public education. It is worth citing Ali Abd al-Razin based at al-Azhar 
University scholar who argues that Islam is a religion and not a state (Rane, 2015). The reality is that ISIS is a state (Kilcullen, 2015a):

"it controls territory and population, governs cities, levies taxes, disposes of substantial economic and military resources, and is in the process of redrawing the map of the entire Middle East through aggressive( largely conventional military conquest". and it needs to be defeated"

But in the process of defeating it we need to be careful not to emulate the monster we contest. Kilcullen cites Nietzsche's 'Beyond Good and Evil'(1886) in his Quarterly essay (no 58) :"Whoever fights monsters should see to it that in the process he does not become a monster. And if you gaze for long into an abyss, the abyss also gazes into you."

One could go further and one could argue that much of the current problem has been created by war and that it is unlikely to be solved by war!

- What does this mean for constructing new forms of civil engagement to address the question: how should we live?

- To what extent does public education a) prepare students to become interested in local government elections (Pilkada) and b) support gender mainstreaming and strategic rights of young people?

Addressing diversity in perceptions is a central concern of public education praxis for better decision making to protect food, energy and water security.

\section{Capacity building through scenarios at the personal, interpersonal and organisational level}

What sectors could be included and on what basis? The need for this research has resulted in the establishment of the Indonesian Research Consortium spanning four universities ( Universitas Nasional, University of Indonesia, Padadjaran, National Islamic University and Flinders). We also have links with a range of Ministries and the West Java Provincial Government. Capacity building though public education involves developing people's capability to address not merely their basic needs, but also their strategic needs, namely their ability to address rights and responsibilities. These include addressing complex, wicked challenges of poverty and climate change. The public education program needs to foster critical systemic praxis and leadership skills to work across cultures, genders and disciplines. Wicked problems comprise many diverse variables that are interred related and that are perceived differently by different stakeholders (Rittel and Webber, 1984, Flood and Carson, 1993). As the nation state increases in size it is increasingly difficult to respond to the diverse needs of citizens and non-citizens. The nation state only protects those who are citizens through the social contract. But non-citizens are not protected and the environment is not protected by nation states that complete for resources.

\section{Participatory Action Research Approach combined with Critical Systemic Policy Analysis}

We propose the need to develop critical participatory action research on learning organisations and learning communities for public education in post national regions. This is needed to protect current and future generations so as to achieve sustainable rural and urban living environments that balance individual and collective needs. 


\section{Learning communities supported by policy research need to contribute to developing insight and foresight.}

Stewardship for future generations underpins the philosophy of Aboriginal custodians of the land and their dreaming sites. However, there is evidence that many non-Aboriginal urban citizens wish to spend more time living slower lives, walking wherever possible, riding bikes, growing local food, recycling and reusing and consuming less, instead of living stressful, competitive lives that save time, but waste resources as they are reliant on fast food in 'throw away' containers, fast travel and a 'time is money attitude' (McIntyre-Mills, 2012a, 2012b,2012c; McIntyre-Mills and De Vries, 2012; McIntyre-Mills et al., 2014). These findings clearly link environmental health and human wellbeing and raise the question of what can we learn from comparing and contrasting mobile versus place-attached people (Vaske and Kobrin, 2001) whose history is recorded in local traditions and local landscapes (Guddemi, 2006; Rose, 2004). Public Education needs to foster stewardship rights and responsibilities (Flannery, 2012). These goals are considered essential for the governance of sustainable resources by Ann Florini (2003) and Carol Graham (2011) of the Brookings Institute. More applied research is needed at the interface of public education, capacity building, knowledge and biodiversity management, consciousness studies and systemic governance (McIntyre-Mills, 2006b, 2010, 2014b) in order to protect human security in terms of food, energy and water.

A learning organization within a learning community and post national region could be designed to be :

- Open to the social, economic and environmental context and responsive to the needs of the people it purports to serve.

- Facilitate opportunities to test out ideas with others.

- Consider self, others and the environment by teaching the ability to think about the consequences of decision making through applying critical heuristics (see Systemic Ethics, McIntyre-Mills, 2014).

Future perceived scenarios necessarily encompass complex social, political, economic, cultural and environmental dimensions (see Kahane 1992:3). Drawing on the Mont Fleur Scenarios, I asked participants in South Africa to think about how scenarios about how we can think differently about food security and the implications for the way we live our lives:

1. What are the implications of denial (or being an ostrich)? Denial leads to 'business as usual' Please give examples in terms of the area of concern, for example food , energy and water security for all.

2. What are the implications of being half hearted (a lame duck)? This means we do too little too late and so we are stuck with the results! Please give examples of how education and employment opportunities for all need to protect the environment.

3. What are the implications of flying too close to the sun (Icarus)? This is an extreme response which could be counterproductive !Please give examples 
4. What are the implications of co-ordinating and working together /flying together for the long haul (being flamingos)? Co-ordinated long haul flight to achieve goals. Please give examples and relate these to the areas of concern by reading/listening to the scenarios and working through the bubble/factor maps, below adapted from the map created by De Vries ( 2008) :

Thinking exercise to support capacity building through facilitating action research for social and environmental justice adapted from User Centric Policy Design (see McIntyre -Mills and De Vries, 2008:308)

1. How does food security / food insecurity help/hinder other aspects of life? For example food enables one to concentrate at school. Lack of food leads to lack of concentration at school.

2. How does the bubble help/hinder other aspects of life? Having food at lunch time means you spend time socializing with others. Not having food at lunch time leaves you hungry, tired and lonely.

3. How important is the bubble? (Use scale like one below) not at all a bit doesn't matter quite important very important

If I solve this problem or have this asset first, does it make solving other problems easier?

4. Do these things always happen together? Or one after another?

5. How do I achieve it?

6. How do I avoid it?

7. Where can I get help for it?

8. Who can I help and how, if they need this or have this problem?

9. Is it sometimes good and sometimes bad - in what situations?

10. Are there other names/terms for the same thing?

11. What can stop me from (or make it really hard) getting/achieving it?

12. Are there conditions I have to meet to achieve/get it? (Such as age, sex, children, income, employment etc. etc.)

13. Is this a smaller or larger part of another issue? (like Physical Health is parent of diabetes)

14. If one thing happens, does another thing usually follow? Both good and bad.

\section{TASK}

- Please map out all the factors that influence food security/in security and how it relates to wellbeing/ lack of wellbeing in your opinion

- Please write under the headings and draw your own pathways about how the bubbles connect

- $\quad$ Add issues/needs/solutions as you discuss and think about things.

- $\quad$ Please work as a group or alone

- Add as many more questions/descriptions as they/you want.

- $\quad$ Add bubbles as well, if you want to. 


\section{Learning organizations span sectors to support non-anthropocentric designs that do not commodify others or the environment}

The rights of sentient creatures were discussed as part of the Asian Conference of Islamic Studies (ACIS) but needs to be translated into practice. The Islamic ban or fatwa on the destruction of endangered animals is one way to try to prevent their demise. Awareness of the need to create sustainable development goals (United Nations, 2013) that respect social, economic and environmental factors is vital .Despite the Dyak's cultural emphasis of the iconic hornbill and its use as a logo for the ACIS conference it faces extinction. The attempts to raise awareness within the region through newspaper articles and airport posters need to be embedded in public education and sanctions to protect the natural heritage on which current and future generations depend:

"It is very important to start a movement for the protection of this near extinct bird. Social organizations like the Dayak Custom Communal Council (DAD) must be engaged in the campaign.... NGOs, activists and academics, working together to arouse public sentiment and make people understand the significance of protecting helmeted hornbills. ....Apart from hunting, population decline is caused by environmental degradation and habitat damage. Forest Watch Indonesia in its 2011 report said the forest destruction in Kalimantan during 2000-2009 was over 36 percent, higher than any other island in Indonesia".

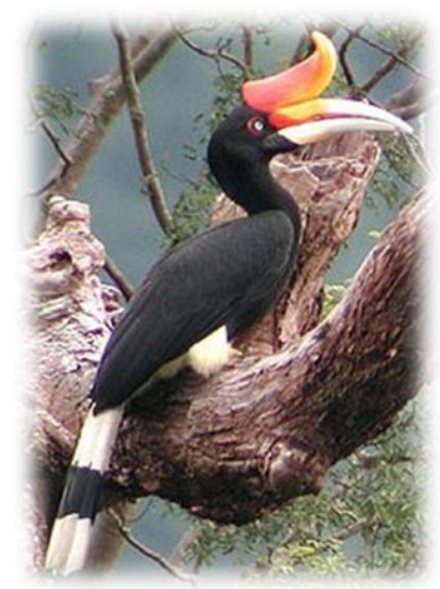

Sourcehttp://fatbirder.com/links_geo/asia/indone sia_kalimantan_selatan.html Accessed $\underline{8 / 06 / 2015}$

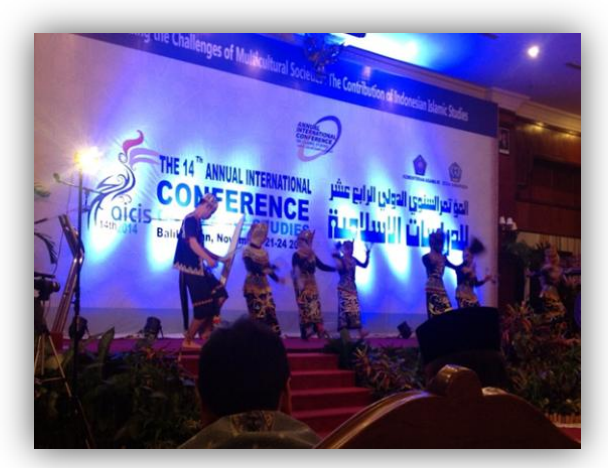

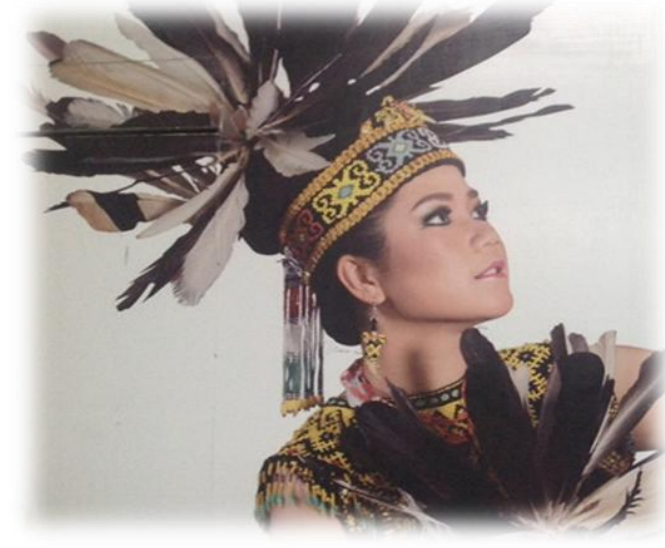

Author's photos taken in Balikapan, December, 2014.

Authors photos taken in Balikapan, December, 2014. 


\section{Co-determination within Biospheres and Rethinking architectures for teaching and learning based on the pillars of morality: empathy and reciprocity}

The social contract extends rights and expects responsibilities to be fulfilled in return. But what about those who are voiceless, disabled, too young or without citizenship rights (displaced, asylum seekers or refugees)? Surely it is time to re-think the social contract which is far too narrowly defined to protect only human animals living within the boundaries of the nation state? Shiva argues that the greatest misuse of natural resources has been by nations and corporations and not by local communities that have acted as water democracies:

"Community rights are necessary for both ecology and democracy. Bureaucratic control by distant and external agencies and markets control by commercial interests and corporations [can] create disincentives for conservation..." (Shiva, 2002: 30-31).

The use of water could be used as a synecdoche for discussing participatory governance and democracy. In South Australia the flow of water has been affected by the introduction of dams and weirs. The upstream users benefit at the expense of down steam users, but this has been raised as a problem by Major Sumner, a Narrinjari caretaker who has stressed that we need to think in terms of cultural flows. This means that our thinking and practice needs to be carefully considered so that we consider the consequences of our policy decisions for ourselves, others and the environment. Stanford research on non-anthropocentric approaches to fairness and unfairness shows that primates and other animals understand the concept of the fair distribution of resources and that a sense of morality and reciprocity guides the behaviour of primates and other animals (including human animals). Frans De Waal stresses the need to recognize that we evolved not only through our ability to compete but through our ability to co-operate and to show empathy to others.

Do we wish to live in a world where we do not want to help one another and in which we deny the pain of sentient beings? (Butler, 2011). If we are prepared to recognize not our resilience, but our mutual vulnerability, it provides a basis for stewardship. We are all reliant on others and need to be able to depend on our connections with others. At a conversation on 'Systemic Ethics' at Schumacher Institute on 26th and 28th August, 2014 we discussed the potential for doing things differently and the notion that despite the rhetoric of the UN Sustainability Agenda. It needs to be implemented in practice through participatory action research that supports public education. The city of Bristol won the Green City award for sustainability as a result of an application developed by the Schumacher institute for setting appropriate benchmarks for achieving sustainable green living. Traffic congestion in the city centre and parking congestion remain challenges, however. A bike project to teach young people how to fix bikes and in the process to earn them is one of the positive steps. We also discussed systemic ethics and the way in which hybridity and our connection with the land are understood by First Nations, such as Aboriginal Australians:

"We read our past in the landscape and we create its future through our choices" (McIntyreMills, 2014, 10). The traditional economic model argues that growth in population helps to sustain the economy. But it is unsustainable and needs to be re-framed. (Stiglitz et al 2010, McIntyre-Mills, et al 2014). The issues facing Australia and the region are of trying to pursue 'business as usual against the tide of social and environmental crisis:

"..[C]ountries must focus on increasing the ambition of their intended reductions, and show these are credible by setting out how they will be achieved through domestic policies and 
legislation" (Stern, 2014, 26).

Profound shifts such as the declaration of the Earth Charter by Bolivia and Ecuador provide inspiration but they need to be implemented through ongoing monitoring from below to ensure that the agenda is indeed sustained:

"..The law, which is part of a complete restructuring of the Bolivian legal system following a change of constitution in 2009, has been heavily influenced by a resurgent indigenous Andean spiritual world view which places the environment and the earth deity known as the Pachamama at the centre of all life. Humans are considered equal to all other entities" (Vidal, 2011).

\section{Conclusion}

My area of concern is to introduce a more responsive and open, transdisciplinary and cross cultural approach to teaching and learning. Instead of making decisions in a top down manner we need to practice democracy from below so that decisions match the needs of local people. The Ghandian moment has arrived. We need to do and use what we can to make a systemic difference. It could be saving seeds, growing food, walking or perhaps finding ways to geo engineer change. It could be speaking respectfully to our local and regional neighbours and creating post national learning communities.

We need to enable educators to develop the capacity to consider the value of many ways of knowing and providing ways to translate thinking into practice through new forms of governance (Beer, 1974, 1994, McIntyre-Mills et al 2014). According to Turok (2012) we need to understand that boundaries in nature can be understood by reflecting on the smallest and largest scales and that we need to make policy decisions based on careful consideration that address who gets what, what, why, how and so what are the consequences?

\section{Collective co-determinism to protect human} security

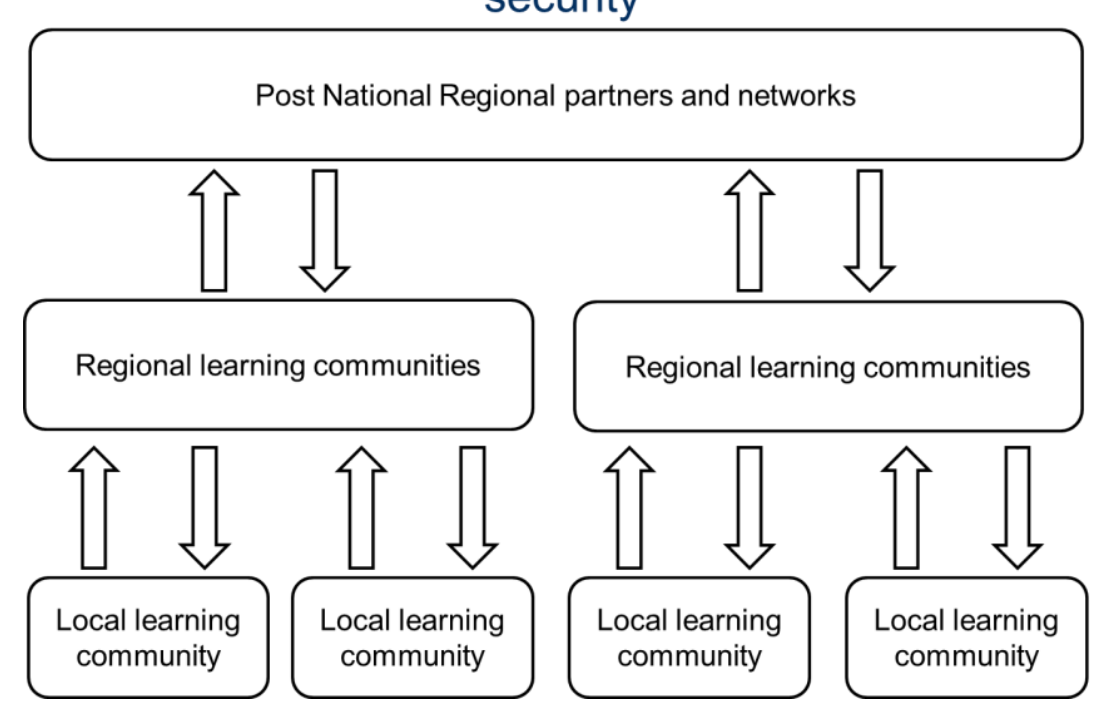

For transformation to occur (McIntyre-Mills, De Vries and Binchai, 2014) being the change involves working across many areas of life, social, economic and environmental and that this could lead to quantum change in the sense used by Turok (2012). The companion volume, Systemic Ethics and Non-anthropocentric Stewardship (McIntyre-Mills, 2014b), explores the 
need to develop the capacity to 'join up the dots' through participatory democracy and governance and through working across disciplines while preserving space for difference, based on the axiom that freedom and diversity need to be fostered to the extent that they do not undermine the rights of others in this generation or future generations of life. Education needs to enable all people to understand our dependence on one another and the land and to protect the wellbeing of current and future generations of life. Turok stresses that the universe and the cell have same physical properties and the cell is perhaps the most complex unit to understand because through understanding its interaction with the environment and the way in which cells respond to signals gives us clues about the nature of consciousness. Turok's parents were anti-apartheid activists who believed in taking on worthwhile challenges and making a difference. This is the approach that Turok has taken. He stresses that once we begin to understand the universe in quantum terms we will begin to move away from either or /zero $/ 1$ approaches and realize that nature is a continuum. He explains that quantum communicators are beginning to help research ongoing emergence and its implications for the way we understand ourselves, others the planet and the universe. In the digital computing paradigm, information is displayed as bits - zero or one - that is computing. But nature does not work that way- it is in motion or continuous. He argues that how we make sense of information is important. More and more information alone is not enough to make a difference.

This point is also made by the socialist feminist, Donna Haraway (2010) who stresses that we are the designers and that we need to take responsibility for what we design. Turok reminds us that if we design Frankenstein's then we will need to take responsibility for them. The city environment is becoming a design with monstrous implications for the way current and future generations live.

Educators and policy researchers need to work together with many stakeholders who can contribute diverse ways of knowing, including non-anthropocentric approaches informed by an understanding of nature and other life forms. It will require our learning the ability to be inclusive by enabling everyone to feel that they are respected and heard. This requires giving time and developing the ability to communicate respectfully across diverse participants that span diverse cultures, interests, experiences and discipline based knowledge. We cannot rely on the $1 \%$ to make the difference and we cannot expect that the powerful will want to make vast changes to the status quo. The temptation to continue to focus on critique of the $1 \%$ along with pleas for transformation is great, but we also need to recognise the banality of evil. The complicity evident in entire societies that do not focus on the elephants in the room, namely that our way of life is unsustainable. And the size of our ecological footprint is too large.

\section{Working across boundaries through co-creating a community of practice to address a shared concern}

Developing a greater number of connections enhances consciousness (Greenfield, 2000, 2003, 2008) who argues that the more we are able to think about our thinking. This can help to create closer bonds with others to foster links and to bridge differences. The approach is as relevant to education as it is to community development and in the process helps to enhance representation and accountability through exploring ideas and engaging in dialogue. Gibbons et al. (1994) argue that the ability to work across boundaries is vital for 'The new production of knowledge' and vital for 'the dynamics of research' to address current complex challenges. The so-called 'tragedy of the commons' argument developed by Hardin (1968) is a construction informed by simplistic thinking. Ironically, it is often used as the starting point 
for environmental thinking, but in fact it originated as an argument developed by Locke in support of the enclosure movement and private property in Britain. The argument being that contained areas of land are cared for better than the areas of land that are held in common and shared. But ironically it is the privatization and commodification of land and natural resources that has led to environmental pollution, degradation and competition for resources.

A Community of Practice (Wenger et al, 2009, Wenger, 1998, needs to enable students to identify with others and to recognize our interconnectedness. The Sydney Peace prize winner Vandana Shiva $(1998,2002,2011)$ sums up the challenge for this century as one of preventing the commodification of life and the importance of thinking about how apparently separate issues are in fact interconnected.

Gro Brundtland (1989) and Mary Kaldor (in Held, 2005: 177) have stressed that human security rests on creating a peaceful world, enshrined in rights expressed in the United Nations Charter (Article 55, 56) and in the constitution of the European Union. Rising living costs led to food riots and the so-called Arab Spring, culminating in the Occupy Wall Street Movement.

Polly Higgins suggests that a new planetary law should be passed to protect the viability of the planet and that current systems of law are inadequate to protect people and the planet (see Shiva and Barlow, 2011, Stiglitz et al , 2010, McIntyre-Mills, 2014a,b). This could help to ensure that elected leaders remain more connected to the people they are supposed to represent. Public Participatory Education needs to build the capacity of people to become leaders in their own right who strive not merely for basic needs but also for social and environmental justice by voicing their concerns strategically. Let us develop a regional approach to public education based on being good neighbours who respect one another's right to privacy but being always ready to talk over the fence when it is clearly an appropriate time. Let us learn to accept diversity and freedom to the extent that it does not undermine the rights of others and let us foster the development of green cities whilst protecting the small farmer on the land. In the words of a farmer who participated at the Schumacher Institute in Bristol, remember the farmer who is 'outstanding in his field!" It means that instead of placing growth only in cities, we need to develop an insight into the importance of protecting agricultural land.

To sum up, we are the land and by recognizing our hybridity and vulnerability we could become more resilient too. We need to protect biodiversity through learning organisations. Education policy needs to support the development of curricula that enables people to join up the dots so that they understand the systemic flow on effects of decisions that affect social and environmental justice for current and future generations of life.

\section{References and further reading}

Aarhus Convention 1998, 'On access to information. Public participation and access to justice in environmental matters',

Denmark,25June.http://aarhusclearinghouse.unece.org/resources.cfm?c=1000069

Akomfrah, J. 2013, The Stuart Hall Project. Documentary produced by David Lawson \& Lina Gopaul and directed by John Akomfrah.

Ali, M., Kos, J., Lietz, P., Nugroho, D., Furqon, Zainul, A., Emilia, E. 2014, 'Quality of Education in Madrasha'. World Bank Report.

Archibugi, D. 2008, 'The architecture of cosmopolitan democracy' in The Global Commonwealth of Citizens: Towards Cosmopolitan Democracy. Princeton University 
Press and also Archibugi, D. 2010. 'The architecture of cosmopolitan democracy', in Brown, G.W. and Held, D.Eds. 2010, Cosmopolitan Reader, Cambridge. Polity Press Arendt, H, 1959, The human condition New York: Doubleday Anchor.

Arendt, H, 1963, Eichmann in Jerusalem: a report on the banality of evil. New York: Viking Press.

Arendt, H. 1972, Crises of the Republic. Harcourt Brace, Orlando. First published in 1969.

Arendt, H. 1967, The Origins of Totalitarianism. London. Allen and Unwin.

Asian Conference of Islamic Studies conference website, http://aicis.stain-samarinda.ac.id/

Aspinal, E. and Fealy, G (Eds) 2003, Local power and politics in Indonesia. Decentralisation and democratisation Indonesian update series. Research School of Pacific and Asian Studies, ANU, 259-274

Australian Public Service Commission 2007, 'Tackling Wicked Problems: A Public Policy Perspective'. Australian Public Service, Canberra

Australian http://www.australianmarriageequality.org/tag/marriage-bills/ accessed 14/06/2015

Australian Broadcasting Association (ABC), 2015, http://www.abc.net.au/news/2015-0316/syria-bound-uk-teens-held-in-custody/6321512. Updated 16 Mar 2015, 12:46pm.

Bider, B 2013 http://m.thejakartapost.com/news/2012/11/13/kalimantan-s-icon-brinkextinction.html-

Bateson, G., 1972, Steps to an Ecology of Mind, Ballantine, New York.

Bausch, K. 2006, 'Be your enemy: The Contributions of West Churchman to Doing Better Governance and International Relations' in McIntyre-Mills, J. Rescuing the Enlightenment from Itself: Critical and Systemic Implications for Democracy, C. West Churchman Series, Vol. 1, Springer, New York, Boston, London.

Beer, S. 1974, Designing Freedom, Wiley, London.

Beer, S. 1994, 'Governance or government' in Beyond Dispute: the invention of team syntegrity. Wiley. London.

Benhabib, S. 2004, The rights of others: Aliens, residents and citizens. Cambridge University Press.

Bishop, J. 2015. http://foreignminister.gov.au/articles/Pages/2015/jb_ar_150317.aspx

Bostrom, N. 2011, 'Existential risk prevention as the most important task for humanity' Faculty of Philosophy \& Oxford Martin School University of Oxford www.existential-risk.org

Bottici, C. and Challand, B 2006, 'Rethinking political myth: the clash of civilizations as a self-fulfilling prophecy'. European Journal of Social Theory 9(3) 315-336.

Boulding, K. 1956, 'General Systems Theory - the skeleton of Science' Management Science. 2, 197-208.

Bowcott, O, 2015 'Human Rights Act repeal would send wrong signal, says Tory peer' http://www.theguardian.com/law/2015/jun/01/human-rights-act-repeal-tory-peer

Brundtland, G. 1987, http://www.worldinbalance.net/agreements/1987-brundtland.html The report "Our Common Future".

Butler, J. 2005, Giving an account of oneself. Fordham University Press.

Butler, J. 2011, 'Precarious Life: The Obligations of Proximity'28/05/2011. The Neale Wheeler Watson Lecture 2011, given by Professor Judith Butler. Location: Nobel Museum, Svenska. http://www.youtube.com/watch?v=KJT69AQtDtg

Capra, F. 1996, The web of life: A new synthesis of mind and matter, Harper Collins.

Carnie, T 2014, 'There is a gold rush to invest in ethanol', Cape Times August $20^{\text {th }}$

Carspecken, P.F. 2014. 'Critical Ethnography in Educational Research'. Routledge. New York 
Christakis, A. and Bausch, K. 2006, How People Harness their Collective Wisdom and Power to Construct the Future in Co-laboratories of democracy, Information Age. Greenwich.

Christakis, A. and Flanagan, T. 2010, The talking point: A collaboration project of 21 st Century Agoras. Information Age Publishing.

Churchman, C. West, 1982, Thought and Wisdom, Californian. Intersystems Publications.

Churchman, C. West., 1971, The Design of Inquiring Systems. New York. Basic Books.

Churchman, C. West., 1979, The Systems Approach and its Enemies. New York. Basic Books.

Collins. R. 2010, 'Geopolitical conditions of internationalism, human rights and world law'. Journal of Globalisation Studies. (1): 29-45.

Comaroff, J. 2011, 'Theory from the South: or how Europe is evolving towards Africa'. Key note address at Knowledge and value in a Globalising world. Disentangling dichotomies, querying unities. University of Western Australia. Perth 5-5th July.

Dawkins, R. 1976, The Selfish Gene Oxford University Press

Dawkins, R. 2006, The God Delusion, Black Swan Berkshire.

De Tocqueville, A. 1945, Democracy in America. New York. Knopf.

De Waal, F. 2009, The Age of Empathy nature's lessons for a kinder society. Harmony.

Dean, A.2015 'Islamic State: Bureaucracy and Brutality' http://www.bbc.co.uk/programmes/ p02gd2wj

Desai, M. 2005, 'Social Democracy as World Panacea. In Held, D. et al. 2005. Debating Globalization. Polity Cambridge.

Douglas, M. 1978, Purity and Danger. An Analysis of the Concepts of Pollution and Taboo, Routledge and Kegan Paul, London.

Dryzek, J. 1999, Democratising Rationality in Discursive Democracy. Cambridge University Press.

Dryzek, J. 2000, Deliberative democracy and beyond. Oxford University Press.

Dryzek, J. 2010, Green democracy, Cunningham Lecture Series, ANU, Occasional Paper.

Dryzek. J. 2005, The politics of the earth. Environmental Discourses 2nd edition Oxford University Press, New York 156-7.

Du Gay, P. 2005, 'Bureaucracy and Liberty: State, Authority and Freedom' in The values of democracy. Oxford University Press.

Elkington, J. 1994, 'Globalisation's reality checks' in Held, H et al Debating globalization, Polity. Cambridge.

Elkington, J., 1997, Cannibals with forks, Oxford. Capstone.

Evans, M.2013, 'Confronting insecure employment 'in Advocate Vol. 20, No 3.p28.

Evatt, H.V. 1984, 'Introduction’ The Eureka Stockade, by Carboni, R. 1855. First edition printed by Atkinson and Co, Melbourne.

Flanagan, T. and Bausch, K. 2011, A democratic approach to sustainable futures. A workbook for addressing the global problematique. Ongoing Emergence Press. Riverdale.

Flannery, T, 2012, 'After the Future: Australia's New Extinction Crisis'. Quarterly Essay Issue 48

Flannery, T. 2005, The weather makers. The history and future impact of climate change. Text Publishing, Melbourne.

Flannery, T. 2010, Here on earth. An argument for hope. Text Publishing. Melbourne

Flood, R. \& Carson, E. 1993, Dealing with Complexity: An Introduction to the Theory and application of Systems Science, 2nd. ed., Plenum, London.

Flood, R. \& Romm, N. 1996, Diversity management: triple loop learning, Wiley, Chichester.

Florini, A., 2003, The Coming Democracy. Island Press, Washington DC.

Flyvberg, B. 1998, 'Habermas and Foucault'. British Journal of Society.49 (2): 200-232 
Folke, C. 2006, 'Resilience: The emergence of a perspective for social-ecological systems analyses'. Global Environmental Change 16 253-267.

Follesdal, A. 2006, 'Subsidiarity, Democracy and Human Rights in Europe'. Journal of Social Philosophy.37 (1):61-80.

Foucault, M. and Gordon, C.1980, Eds., Power/Knowledge. Harvester. Brighton.

Fougere, G. 2007, 'Wellbeing is an idea whose time has come.' New Opportunities for Health Impact Assessment in New Zealand public policy and planning. The Public Health Advisory Committee. Wellington, New Zealand.

Fourade, M. And Savelsburg, J. 2006, 'Global Processes, National Institutions, Local Bricolage: shaping law in an era of globalisation'. Law and Social Inquiry. Vol. 31.3, pp. 515-519.

Fraser, G. 2015. Tradition of iconoclasm: the Charlie Hebdo cartoonists were part of a history of attacking divine representations The Guardian Weekly 16/01/15 18-19.

Tradition of iconoclasm: the Charlie Hebdo cartoonists were part of a history of attacking divine representations The Guardian Weekly 16/01/15 18-19.

Frank. R.H. 2007, Falling behind: how rising inequality harms the middle class, Berkley, CA. California Press.

Friere, P. 1982, 'Creating alternative research methods: learning to do it'. In Hall, B. Gillete, A., and Tandon, R. Eds., Creating Knowledge: A Monopoly? New Delhi Society for Participatory Action Research in Asia, pp. 29-37.

Gandhi, L. 1966, Affective communities: anti-colonial thought, fin-de-siècle radicalism and the politics of friendship, Duke University Press.

Getano Lui, 1993, Voices from the Land. Boyer lecture Series.

Gibbons, M. Limoges, C., Nowotny, H., Schwartzman, S., Scott, P. \& Trow, M. 1994. The New Production of Knowledge: The dynamics of Science and Research in Contemporary Societies, London. Sage.

Giddens, A. 2009, The politics of climate change. Polity. Cambridge

Goldenburg, S. 2013 Up to 1 bn a year spent fighting action on climate change The Guardian Weekly, 3/1/ 2014page 11

Gould, C. 2007, 'Transnational Solidarities' Journal of Social Philosophy, 38(1), 148-164.

Graham, C. 2011, The pursuit of happiness: an economy of well-being. Brookings Institution Press. Washington.

Greenfield, S. 2000, The private life of the brain: emotions, consciousness and the secret of the self. Wiley. New York

Greenfield, 2003, Tomorrow's People How 21st Century Technology is changing the way we think and feel. Penguin

Greenfield, S. 2008, ID: The quest for meaning in the 21st century. Sceptre, Hodder and Stoughton, London.

Greenwald, G. 2012, 'New York's top court highlights the meaninglessness and menace of the term 'terrorism'” http:/www.guardian.co.uk/commentisfree/2012/dec/16/courtterrorism-morales-gangs-meaningless.

Gower, M. 2015, Deprivation of British citizenship and withdrawal of passport facilities Standard Note: SN/HA/6820, last updated: 30 January 2015, Author: Melanie Gower, Section Home Affairs Section http://researchbriefings.files.parliament.uk/documents/SN06820/SN06820.pdf, and accessed 8/06/2015.

Guddemi, P. 2006, 'Human views of ecological nature'. Cybernetics and Human Knowing. 12(1): 86-90.

Hall, S and Du Gay, P. 1996, Cultural Identity. Sage. London 
Hall, S. 1997. Representation: Cultural Representations and Signifying Practices. London: SAGE Publications Ltd presentation

Haraway, D. 1991, The reinvention of nature. Free Association Books. London.

Haraway, D. 2010, 'Speculative fabulations for technoculture's generations: taking care of unexpected country', Australian University E press. http://epress.anu.edu.au/guidelines/author_guidelines.html

Hardin, G. 1968, 'The Tragedy of the Commons', Science, 162:1243-1248.

Harrison, K. 2002, 'Policy perspectives: Social Capital'. In Parnell, S. Swilling, M and Wooldridge, D. Democratising local government. The South African experiment. University of Cape Town Press. Landsdowne.

Hayden, P. 2010, 'The environment, global justice and world environmental citizenship'. In Brown, G.W. and Held, D. Cosmopolitanism, Polity Cambridge

Held, D., McGrew, A., Goldblatt, D. \& Perraton, 1999, Global transformations. Politics Economics and Culture. Stanford University Press. Stanford California

Held, D.2004, Global Covenant: The Social Democratic Alternative to the Washington Consensus. Polity

Held, D. et al. 2005, Debating Globalization. Polity Cambridge.

Held, D.2004, Global Covenant: The Social Democratic Alternative to the Washington Consensus. Polity.

Henderson, G 2015, 'Concession that led to an immigration debacle' The Australian, May 23-24, pg 16

Higgins, P. 2013, 'Dare to be great' TEDx, Whitechapel, Published on Feb 13, 2013

Hill Collins, P. 2000, Black Feminist Thought: Knowledge, Consciousness and the politics of Empowerment. Routledge. New York.

HM Government 2005, 'Securing the Future: Delivering UK Sustainable Development'. Strategy Presented to Parliament by the Secretary of State for Environment, Food and Rural Affairs by Command of Her Majesty, March 2005. HMSO: St Clements House, 2-16 Colegate, Norwich.

Hobbes, T. Leviathan, http://ebooks.adelaide.edu.au/h/hobbes/thomas/h681/index.html accessed 25/06/2012

Hobson-West, P. 2007, 'Beasts and Boundaries: an introduction to animals in sociology', Science and Society. Qualitative Sociology Review. Vol. 3 Issue 1. 23-41

Hoggett, P. 2010, Politics, Identity and Emotion. Paradigm, Boulder.

Hoggett, P. and Thomson, S. 2002, 'Towards a democracy of emotions'. Constellations, 9 no1.102-126.

Horvath, Z. and Odor, B. The Union after Lisbon. The treaty reform of the EU. HVG-ORAC Publishing. Hungary.

http://www.eurozine.com/articles/2006-12-23-baubock-en.html Accessed 19 December, 2012.

Hulme, M. 2009, Why we disagree about climate change. Cambridge. University Press

Hulme, M. 2010, 'Cosmopolitan Climates. Hybridity, Foresight and meaning'. Theory, Culture and Society. Vol. 27 (2-3): 267-276.

Hulme, M. 2011, 'Climate Change and four narratives of growth'. AHTC Workshop. University of Cambridge. http://climatehistories.innerasiaresearch.org/wpcontent/uploads/2011/01/Mike-Hulme.pdf. Accessed 8 Feb 2011.

Huntington, S.1996, The clash of cultures and the remaking of the world order. New York. Simon and Schuster.

Huntington, S. 1993, 'The clash of civilisations?' Foreign Affairs, summer, 1993, pp22-49 icps.gwu.edu/“The Good Life: An International Perspective,” There's a Future: Visions for a better world 
https://docs.google.com/viewer?a=v\&q=cache:8rnWNHvfIcAJ:icps.gwu.edu/files/201 3/02/The-Good-Life-An-International-

Perspective.pdf + the + good + life ++ an + international+perspective $+\% 2 \mathrm{~B}+\mathrm{etzioni} \& \mathrm{hl}=\mathrm{en}$ $\& g l=a u \&$ pid=bl\&srcid=ADGEESgpk7jXTiA7uWJH2nWGJm4gOc8rGDjuAHmoeyW7IQ1

Ingold, T. 1993. 'The temporality of the landscape', World Archaeology. Vol. 25 No 2 Conceptions of time and ancient society. Oct 152-174.

International Commission on the Future of Food and Agriculture 2007 Manifesto on the future of seeds www.future-food.org

Indonesian Government http://www.indonezia.ro/republic.htm: Pancasila Irvin, R.Stansbury, J.2002, 'Citizen Participation in decision making'. Public Administrative Review. Vol. 64:1:55-65.

Irvine, L. 2007, 'The question of Animal Selves: implications for sociological knowledge and practice'. Qualitative Sociology Review. Vol. 3 Issue 1. 5-22.

Ison, R. 2005, 'Geoffrey Vickers: Contemporary Applications and Changing Appreciative Settings' Systems Research and Behavioural Science, Vol. 22 No.4 July-Aug. 277284.

Jackson, M. 1991, Systems Methodology for the Management Sciences, Plenum. London.

Jasonoff, S. 2003, 'Technologies of humility: citizen participation' in governing science. Minerva. 41:223-44.

Jessop, S. 2009, 'Children's participation: an Arendtian criticism'. Educational Philosophy and Theory. Vol. 43. No 9 Article first published online: 8 NOV 2009 DOI: $10.1111 /$ j.1469-5812.2009.00560.x.

Kabeer, N \& Subrahmanian, R 1996, 'Institutions, relations and outcomes: framework and tools for Gender-Aware Planning', Institute of Development Studies Discussion Paper, No. 357, Brighton, UK.

Kahane, A. 1992, Mont Fleur Scenarios http://www.democraticdialoguenetwork.org/documents/view.pl?s=14;ss=;t=;f_id=227

Kazniak, A. 2014, Aging, Mindfulness and the Brain Plenary Paper presented to the Mindfulness Matters Conference (2014), Stellenbosch, South Africa, http://www.mindfulness.org.za/mindfulness2014/conference-speakers/\#alfred

Keane, J. 2009, The life and death of democracy. Simon and Schuster. London.

Kickert, W.JM, Klijn, E.H. and Koppenjan, J.F.M. 1999. Managing Complex networks: Strategies for the Public Sector. Sage. London.

Kilcullen, D. 2015. Ramp up the force to defeat Islamic State The Australian, May 23-24, pg. 16

Kilcullen, D. 2015 'Blood Year'. Quarterly Essay, No 58

Kingsbury, D. 2014. 'Don't expect Indonesian support for tow backs' http://www.abc.net.au/news/2014-10-27/kingsbury-turning-back-the-boats/5844926.

Kingsly, P, 2015, 700 migrants feared dead in Mediterranean shipwreck, The Guardian http://www.theguardian.com/world/2015/apr/19/700-migrants-feared-deadmediterranean-shipwreck-worst-yet

Lincoln, Y, 2001 'Engaging sympathies' in Action Research Handbook Edited by Reason, P. and Bradbury, H. Sage. London.pp124-132

Max-Neef, M. 1991, Human Scale Development. Apex. London.

Meadows, D. \& Randers, J., 1992, Beyond the Limits. Global Collapse of a Sustainable Future, Earthscan Publications, London.

Midgley, G. 2000, Systemic Intervention: Philosophy, Methodology, and Practice. Kluwer. New York. 
Mangcu, X 2014, The arrogance of power: South Africa's leadership meltdown. Tafelburg. Cape Town

McRae, D. 2013, 'Challenges ahead for the Indonesia relationship'

http://www.abc.net.au/news/2013-10-02/mcrae-challenges-ahead-for-the-indonesiarelationship/4993720

McIntyre-Mills, J. 2000, Global Citizenship and Social Movements: Creating Transcultural Webs of Meaning for the New Millennium. The Netherlands: Harwood.

McIntyre-Mills, J. Editor 2006a, 'Rescuing the Enlightenment from Itself: Critical and Systemic Implications for democracy’. C.West Churchman Series, Vol. 1. Springer. London. ISBN -10 0-387 27587-8, ISBN -10: 0387-27

McIntyre-Mills, J. 2006b, 'Systemic Governance and Accountability: working and re-working the conceptual and spatial boundaries of international relations and governance'.

Volume 3 of the 'C. West Churchman and Related Works Series', Springer, London.

McIntyre-Mills, J 2010, 'Wellbeing, mindfulness and the global commons'. Journal of Consciousness Studies. 17, (7-8) 44-72.

McIntyre-Mills, J with Binchai, N and De Vries, D. 2014, 'From Wall Street to Wellbeing: Joining up the dots through Participatory Democracy and Governance to mitigate the causes and Adapt to the effects of climate change' Springer, New York.

McIntyre-Mills, J 2014a. 'Systemic ethics and non-anthropocentric stewardship: Implications for transdisciplinarity and cosmopolitan politics. Springer, New York

McIntyre-Mills, J 2014b, 'Reconsidering boundaries', Sociopedia.isa, DOI: 10.1177/2056846014102, Sociopedia.isa

McIntyre-Mills, J 2014d, 'Multicultural Education in Indonesia: Challenges and Opportunities: From Clash of civilisations to co-creation and co-determination' 21-23 November 2014 Balikapan, plenary paper at Annual International Conference of Islamic Studies (AICIS) http://aicis.stain-samarinda.ac.id/

McIntyre-Mills, J, Kedibone, G.M, Arko-Achemfuor, Manunda, P, Njiro, E, 2014a, 'Participatory approach to education: an action learning approach at the University of South Africa' Participatory Education Research vol1 (2)106-132.

McIntyre-Mills, J 2014b, Systemic Ethics' Springer Encyclopedia of Food Ethics ISBN 97894-007-0928-7

McIntyre-Mills, J 2014c, Systemic ethics and non-anthropocentric stewardship: Implications for transdisciplinarity and cosmopolitan politics Springer, New York.

McIntyre-Mills, J 2014d, 'Reconsidering Boundaries' Sociopedia.isa, DOI: $10.1177 / 2056846014102$

McIntyre-Mills, J with De Vries, D and Binchai, N. 2014g, 'Wall Street to Wellbeing: Joining up the dots through participatory democracy and governance to mitigate the causes and adapt to the effects of climate change:' Springer, New York.

McIntyre-Mills, J, 2015, Presentation at the Science_of_Dialogic_Design,World Futures Institute, 2-8 May, Cyprus.

http://www.futureworlds.eu/wiki/The_2015_International_Conference_on the Science_of_D ialogic_Design:_Symposia_for_Scientists_and_Practitioners

McKay, V. and Romm, N. 1992. 'People's Education in Theoretical Perspective'. Mascew Miller. Cape Town.

Muhammad Adib Shomad 2014 'A comparative case study of a secular and religious-based university in Indonesia: a critical review of research capacity'

Nussbaum, M., 2006, 'Frontiers of Justice', London. Harvard University Press.

Parker, J. 2012, 'Transdisciplinary systems approach to paradigm change in sustainable economy' in The Systemist, Volume 34, No. 3, Winter 2012, pp138-149 
Pratikno, 2014, 'Fostering Indonesian and Australian friendship: put education and culture first' Flinders University Seminar on Rumah Budaya, April.

Porter, H and Hirsch, A. 2015, http://www.theguardian.com/commentisfree/2009/feb/06/surveillance-lords-libertycentral.Romm, N. 2001, 'Accountability in Social Research: issues and debates'. Kluwer. London.

Romm, N. 2010, 'The New Racism'. Springer. London.

Romm,N. 2002 , 'A trusting constuctivist view of Systems Thinking in a Knowledge Age in Systems Theory and Practice in a Knowledge Age'. In Ragsdell et al .New York. Plenum.

Rosyada, D. 2014, 'Islamic Education in Indonesia'. Flinders University Seminar on Rumah Budaya, April.

Shiva, V 2002, Water wars: privatization, pollution and profit, London, Pluto Press.

Shiva, V. 2011, Earth Democracy, Portland University, http://www.youtube.com/watch?v=UOfM7QD7-kk/

Shiva, V. 1989, Staying Alive: Women, ecology and survival in India, Zed Books. London

Shiva, V and Barlow, M. 2011, 'Democracy Now Earth Day Special' Vandana Shiva and Maude Barlow on the Rights of Mother Earth' Apr 22, https://www.youtube.com/watch?v=Bq0lrbznsjc\&app

Silverstein, J. and Kaiser, M. 2014, Who Welcomes Who in Multicultural Australia? Oct 2nnd https://newmatilda.com/2014/10/02/who-welcomes-who-multicultural-australia

Urry, J. 2010, 'Consuming the planet to excess'. Theory, Culture and Society. Vol. 27 191212

Widianingsih, I. 2014, 'International Donor Policy \& Local Government in Indonesia: Establishing Good Governance?' Unpublished PhD thesis, Flinders University, School of Social and Policy Studies.

Mason, R.2014 Apathetic and disaffected: millions who may never vote: the young and poor shun the ballot box but experts disagree on solutions The Guardian Weekly, 3/1/ 2014page15

McCrae, D. 2013. http://www.abc.net.au/news/2013-10-02/mcrae-challenges-ahead-for-theindonesia-relationship/4993720 accessed 15/06/2015

Murray, J. Dey, C. and Lenzen, M. 2007, 'Systems for Social Sustainability: Global Connectedness and the Tuvalu Test'. Cybernetics and Human Knowing. Vol. 14 No 1: $87-105$.

Murray_et_al_2006, Systems for Social Sustainability: Global Connectedness and the Tuvalu Test. Tuvalu at the Common Wealth Games, Melbourne, 2006. Photograph by Geoff Ludbrookwww.isa.org.usyd.edu.au/publications/documents/ Tuvalu_Test.pdf

Municipal Service, 2014, http://www.etu.org.za/toolbox/docs/localgov/munservice.html Musgrave, A. 2015 'More people living below breadline, says Stats SA' The Star, pg. 4 Nazarea, V. 2006. 'Local knowledge and memory in biodiversity conservation', Annual Review of Anthropology. Vol. 36.pp 317-335.

Nussbaum, M. \& Glover, J. 1995, Women, Culture and Development: A study of Human Capabilities. Oxford. Clarendon Press

Nussbaum, M. 1986, The fragility of goodness: luck and ethics in Greek tragedy and philosophy. Cambridge. University Press.

Nussbaum, M., 2006, Frontiers of Justice, London. Harvard University Press.

Olding, R. 2015, 'Emotions run high for Australia's Muslim youth risking all to fight in the Syrian war' Sydney Morning Herald.

Parker, J. 2012, 'Transdisciplinary systems approach to paradigm change in sustainable economy' in The Systemist, Volume 34, No. 3, Winter 2012, pp138-149 
Parry, M. Rosenzweig, C., Iglesias, A. Fischer, G. and Livermore, M. 1999, 'Climate change and world food security: a new assessment Global Environmental Change.S51-S67 Elsevier . Available online 25 October. Accessed February, 7th, 2011.

Pretty, J. 2013, 'The consumption of a Finite Planet: Well-being, Convergence, Divergence and the Nascent Green Economy'. Environmental and Resource Economics. DOI $10.1007 / \mathrm{s} 10640-013-9680-9$

Poe, D. 2010, 'Subsidiarity and the bias for the local', Journal of Globalisation Studies Vol. 1.131-140.

Port, $\mathrm{H}$ and Hirsch, A. 2015, 'Civil liberties: The House of Lords report: a devastating analysis'

http://www.theguardian.com/commentisfree/2009/feb/06/surveillance-lords-liberty-central.

Rane, H 2015. 'The notion that Western and Muslim are opposite identities is mistaken' The Australian, May 23-24, pg. 17

Reason, P. 2002, 'Justice, sustainability and participation', Concepts and Transformations, Vol.7 (1): 7-29.

Ritchey, T. 2011, Wicked Problems - Social Messes Risk, Governance and Society, Volume 17, 2011, pp. 1-6

Rittel, H. and Webber, M. 1984, Planning problems are wicked problems Developments in Design Methodology. New York: Wiley.

Rockström, J., Steffen, W., Noone, K. 2009, 'A safe operating space for humanity' Nature 461: 472-475

Rogers, S. 2015. Statistics lay bare stark economic disparities and social disparities. The Australian, May 23-24, pg. 15

Rose, D.B. 1996 Nourishing terrains: Australian aboriginal views of landscape and wilderness. Australian Heritage Commission, Canberra, ACT, BCIN Number: 236409

Rose, D.B. 2005, 'Dislocating the Frontier' http://epress.anu.edu.au/dtf/html/frames.php see http://epress.anu.edu.au

Rose, D.B.2004, Reports form a wild country. University of New South Wales Press. Sydney.

Rosen, R. 1991, Life Itself: a comprehensive inquiry into the nature, origin and fabrication of life. Columbia University Press. New York.

Sajjad (2013) A 'non-western' reading of the 'clash of civilizations' theory: through the eyes of 'the rest'. International Journal of Political Science and Development Vol. 1(2), pp. 42-104, October 2013 DOI: 10.14662/IJPSD2013.005

Scammell, R. 2015 'Migrant arrivals in Italy pass 50 000' The Guardian Weekly, 12.06.2015.

Schumacher, F.F. 1973, Small is beautiful. Economics as if people mattered. Harper and Row. New York.

Scott, J. 1998 Seeing like a state. Yale University Press.

Shiva, V. 1988 Staying Alive: women, ecology and development. South End Press. New York

Shiva, V 2002, Water wars: privatization, pollution and profit, London, Pluto Press.

Shiva, V. 2011, Earth Democracy, Portland University, http://www.youtube.com/watch?v=UOfM7QD7-kk/

Singer, P., 2002, One World: The Ethics of Globalisation, Text Publishers, Melbourne.

Stanescu, J. 2012, 'Species Trouble: Judith Butler, Mourning, and the Precarious Lives of Animals', Hypatia VL - 27, 563-582.

Steffen, W. Burbridge, A. Hughes, L. Kitching, R., Lindenmayer, D. Musgrave, W. Stafford Smith, M. and Werner, P. 2009, 'Australia's Biodiversity and Climate Change'. Australian Government. CSIRO publishing.

Stern, N, 2007, The Economics of Climate Change. Cambridge. Cambridge University Press 
Stern, N 2014, Our path on climate change is uncertain: a global warming pact has been struck, but now nations must not only meet targets but fund clean development. The Guardian Weekly, 19.12. 2014

Stiglitz, J. Sen, A. And Fitoussi, J.P. 2010, Mis-measuring our lives: why the GDP doesn't add up. The New Press. New York,

Stiglitz, Joseph E. 2012, The Price of Inequality: How Today's Divided Society Endangers Our Future. WW Norton.

Sydney Peace Foundation citations

http://sydneypeacefoundation.org.au/?s=Julian+assange\&submit.x=-696\&submit. $y=-$ 246\&submit=Go he Director of the Sydney Peace Foundation, Citation: 'Assange's work is in the Tom Paine Rights of Man and Daniel Ellsberg Pentagon Papers tradition- challenging the old order of power in politics and in journalism. Assange has championed people's right to know and has challenged the centuries old tradition that governments are entitled to keep the public in a state of ignorance...'

$\mathrm{http}$ ///sydneypeacefoundation.org.au/peace-prize-recipients/2010-dr-vandana-shiva/ Citation : "Recognised for her courageous leadership of movements for social justice - the empowerment of women in developing countries, advocacy of the human rights of small farming communities and for her scientific analysis of environmental sustainability"..

http://sydneypeacefoundation.org.au/peace-prize-recipients/2014-julian-burnside-ao-qc/"

Citation : " for his brave and principled advocacy for human rights and for those wronged by government, for insisting that we respect our international obligations toward those seeking asylum, and for his unflinching defence of the rule of law as a means to achieve a more peaceful and just society"

Turok, N. 2012, The universe within Allen and Unwin. Based on the CBC Massy Lectures Treaty of Maastricht 1992. Article 5 on Subsidiarity.

Triggs, G. (2015) http://www.theguardian.com/australia-news/2015/jun/06/gillian-triggsslams-scores-of-laws-threatening-fundamental-freedoms)

Ulrich, W. 1983, Critical heuristics of social planning: a new approach to practical philosophy. Wiley. New York.

UNESCO, 2007, 'Biosphere Reserves: Dialogue in biosphere reserves'. References, Practices and Experiences. ISSN 2071-1468. Paris. UNESCO

United Nations.1993, Integrated Environmental and Economic Accounting: Handbook of National Accounting: Studies in Methods, Series F. No 61, Department for Economic and Social Information and Policy Analysis, Statistical Division, United Nations, New York.

United Nations Economic and Social Development Local Agenda 211992.

United Nations Human Development Index 2003 A compact among nations to end poverty. UNDP. New York. Oxford University Press.

United Nations Climate Change Summit, 2009. The Copenhagen summit (2009) United Nations Climate Change Summit https://unfccc.int/meetings/copenhagen_dec_2009/meeting/6295.php

United Nations Climate Change Summit, Cancun (2010) United Nations Climate Change Summit https://unfccc.int/meetings/cancun_nov_2010/meeting/6266.php

United Nations Climate Change Summit, Durban 2011 United Nations Climate Change Summit https://unfccc.int/meetings/durban_nov_2011/meeting/6245.php

United Nations 2013. Working Group on Sustainable Development Goals. "First session of the Open Working Group on Sustainable Development Goals.

http://sustainabledevelopment.un.org/?menu=1300 
UNHCR Remarks by António Guterres, United Nations High Commissioner for Refugees, Second International Humanitarian Pledging Conference for Syria, Statements by High Commissioner, 15 January 2014, http://www.unhcr.org/52d692429.html.

UNICEF, 2015 SAPA, "Generation 2030 Africa" report cited by http://www.news24.com/Tags/Places/johannesburg

Urry, J. 2007, Mobilities. Cambridge. Polity.

Urry, J. 2010, 'Consuming the planet to excess'. Theory, Culture and Society. Vol. 27 191212

Vaske, J. and Kobrin, K. 2001, 'Place attachment and environmentally responsible behavior'. Journal of Environmental Education. Vol. 32, No. 4. Pp16-21.

Vanstone, A. 2015, http://www.theguardian.com/australia-news/2015/jun/08/amandavanstone-says-she-despaired-at-her-partys-proposal-to-strip-citizenship)

Van Bruinessen, M, 2011, 'What happened to the smiling face of Indonesian Islam? Muslim intellectualism and the conservative turn in post Suharto Indonesia' RSIS working paper series, no 22.

Vidal, J, 2011, 'Bolivia enshrines natural world's rights with equal status for Mother Earth' http://www.theguardian.com/environment/2011/apr/10/bolivia-enshrines-naturalworlds-rights

http://www.ipsnews.net/2011/05/global-campaign-to-bestow-legal-rights-on-mother-earth/ https://www.youtube.com/watch? $\mathrm{v}=\mathrm{QPUmN88htCo}$ and Earth democracy http://m.youtube.com/watch?v=Bq0lrbznsjc.

Vaughn, A., 2014, Tax on meat will cut methane build up The Guardian Weekly, 3/1/ 2014, page 11

Widodo, J., 2014, http://blogs.wsj.com/searealtime/2014/10/20/as-it-happens-indonesiainaugurates-joko-widodo-as-president/ Accessed 21/10/2014

Wilkinson, R. and Pickett, K. 2009, The Spirit Level. Why more equal societies almost always do better. London. Allen Lane

Wadsworth, Y. 2010. Building in Research and Evaluation. Human Inquiry for living systems. Allen and Unwin. Sydney

Wenger, E, White, N. and Smith, J. 2009, Digital Habitats: stewarding technology for communities. CP Square, Portland.

Wenger, E., 1998, Communities of Practice. Cambridge University Press.

Whyte, S. 2015 Abott dodges q questions-on-people smuggler-payment-claims Sydney Morning Herald, http://www.smh.com.au/federal-politics/political-news/primeminister-tony-abbott-dodges-questions-on-peoplesmuggler-payment-claims20150614-ghnger.html

Widianingsih, I. 2014 'International Donor Policy \& Local Government in Indonesia: Establishing Good Governance?'

Wilkinson, R. and Pickett, K. 2009 The Spirit Level. London. Allen Lane

Wynne, B. 1996. 'May the sheep safely graze? A reflexive view of the expert-lay knowledge divide' in Lash, S. Szerszynski and Wynne, B. Risk, environment and modernity: towards a new ecology. Sage. London.

Xalabile, N. 2013 'Marikana: one year after the massacre: Special Report on the consequences of the killings through the eyes and voices of those most affected: the families of the dead miners'

http://marikana.mg.co.za/\#families_xalabile Mail and Guardian accessed 13/08/2014 Young, I.M., 2000, Inclusion and democracy. Oxford. Oxford University Press.

Younge, G. 2015 The danger of polarized debate is all too real: the truth about the Paris attacks is more complex and more difficult than many would like to accept The Guardian Weekly 16/01/2015.18-19 